\title{
Development of Taiwan Teacher's Sense of Community Scale-From Perspective of Workplace Spirituality
}

\author{
Wu Ho-Tang ${ }^{1}$, Chou Mei-Jü,* \\ ${ }^{1}$ Department of Education, National Kaohsiung Normal University, Taiwan \\ ${ }^{2}$ Early Childhood Education and Center for Teacher Education, National Pingtung University, Taiwan
}

Copyright (C) 2015 by authors, all rights reserved. Authors agree that this article remains permanently open access under the terms of the Creative Commons Attribution License 4.0 International License

\begin{abstract}
This research aims to develop Taiwan Teacher's Sense of Community Scale, because there are rare(is no) sense of community scales for teacher in Taiwan. In process of developing the scale, we had three procedures: 1. Literature analysis: the relevant theoretical foundation includes sociology, sociological psychology, and etc., this research adopted workplace spirituality, since sense of community is one dimension in some workplace spirituality scales, and it can be further divided into sense of connection, sense of support, and sense of having the same purposes. Therefore, our research takes sense of community as the variable and the just mentioned three points as the dimensions. After literature analysis, 14 items were proposed. 2. Reviewed by experts: Four experts provided opinions for us to modify the initial 14 items from theoretical and practical perspectives, and the results are-- 8 items remained the same, and 6 were modified. 3. CFA: The items were further inspected by three models. (1) The initial model: The 14 items of the three factors were edited into a Likert five-point-scale, and first-order CFA model to confirm their fit, and the result showed that the overall model was fair $(N=235)$, although one item's factor loading was only .36, yet it was deleted. (2) Modification Model: The model after deleting the item was called modification model with fair results after our confirmation. Further analysis was conducted for the basic fit of the modification model, and it is found that there were no offending estimates, and the fit of the internal structure was acceptable (including the individual reliability, the composite reliability, the average variance extraction). 3 . The review model: Due to that the model was modified, another batch of the samples was investigated $(N=378)$ for confirmation of the model's stability. Since the overall results were fit; up to now, the 13 items of the three factors' Sense of Community Scale for the teachers was established, including sense of connection (4 items), sense of support (5 items), and sense of common purposes (4 items).
\end{abstract}

Keywords CFA, Sense of Community, Workplace Spirituality

\section{Introduction}

This research aims to develop Taiwan Teacher's Sense of Community Scale for teacher in Taiwan. Sense of Community (SOC) has been studied in a variety of contexts such as neighborhoods, psychosocial rehabilitation programs, community organizations, workplaces, and faith institutions, as well as with youth, immigrant communities, firefighters, and an international community of interest. This breadth of application highlights the importance of the construct to a diverse array of settings and populations in community-based research and practice (Peterson, Speer, \& McMillan, 2008)[1]. Primarily, sense of community is to shape a supportive culture (Cohn \& kottkamp, 1993)[2], because of its emphasis on membership. That is to say, if the members in a community know one another, their sense of security, belonging, trust, and acceptance will be raised through emotional disclosure to one another and close behaviors (McMillan, 1996) [3]. Besides, SOC has positive associations with social cohesion (Wilkinson, 2007) [4], place attachment (Long \& Perkins, 2007) [5] and sense of safety (Zani Cicognani, \& Albanesi, 2001) [6], if employees are provided with sense of community at workplace, then they are satisfied with their life (Bodla, Afza, Ali, \& Naeem, 2015) [7]. It is therefore learned the importance of SOC. However, there are no studies on teacher's sense of community currently due to a lack of teacher's sense of community scales. As a result, this research aims to develop Teacher's Sense of Community Scale.

Since SOC has a variety of theoretical foundations, it has diversified definitions and dimensions as well. For example, from the cutting angle of sociology, Doolittle and MacDonald (1978) [8] held that "sense of community" is a term used frequently by social scientists to describe patterns of relationships and the quality of life in urban neighborhoods. As the Sense of Community Scale developed by the above mentioned two scholars, this scale labeled these 
factors: 1.Supportive Climate: a climate particularly conducive to frequent and satisfying informal interaction among residents of the neighborhoods. 2. Family Life Cycle: tends to affect concern about and participation in the life of the local, neighborhood area. 3. Safety: it reflects an assessment of safety. 4. Informal Interaction: provide an arena for socialization and expressive communication. 5 . Neighborly Integration: neighborhoods are settings for close ties and frequent interactions among residents. 6. Localism: emphasize involvement in formal neighborhood organizations and the importance of local talkspots, and tend to have diffusely geographic shopping habits.

On the other side, from the perspective of sociological psychology, McMillan and Chavis's (1986)[9] defined sense of community as: a feeling that members have of belonging, a feeling that members matter to one another and to the group, and a shared faith that members' needs will be met through their commitment to be together. There are four dimensions in their scale: 1. Membership: a sense of belonging and identification. 2. Influence: members need to feel that they have some influence in the group, and some influence by the group on its members is needed for group cohesion. 3 . Integration and fulfillment of needs: Members feel rewarded in some way for their participation in the community. 4 . Shared emotional connection: it includes shared history and shared participation.

To make a step further, sense of community is also probed from the point-of-view of workplace spirituality. Actually, workplace spirituality-based sense of community often appears in some scales of workplace spirituality, which involves the effort to find one's ultimate purpose in life, to develop a strong connection to coworkers and other people associated with work, and to have consistency (or alignment) between one's core beliefs and the values of their organization (Mitroff \& Denton, 1999)[10]. Miller (1992)[11] is a good example. He started from workplace spirituality to point out that sense of community in respect with work is to view one's relationship with others, including his or her support the colleagues, on basis of the inner self, so that he or she can liberally express cozy feelings like care. Also, Ashmos and Duchon (2000) [12] referred to SOC as interaction of care and behaviors among the colleagues, which proves that SOC with workplace spirituality perspective involves interpersonal interaction among coworkers in workplace. Consequently, sense of community from workplace spirituality is divergent from the previously mentioned sociology and sociological psychology points-of-view. Additionally, Bodla et al(2015)[7] made a survey of the role of psychological sense of community in enhancing employee's well-being with 8 items measuring SOC taken from Ashmos and Duchon' Spirituality at Work, and SOC is but one dimension in this scale in addition to dimensions of meaningful work, community, and inner life. Similarly, it is obvious that sense of community can be regarded as a research variable.

Lastly, workplace spirituality focuses on raising the personal inner spirituality, while wage, work duration, and the pension system are all protected by laws in Taiwan teachers. Teachers in Taiwan belong to high socio-economic status, and they enjoy high prestige from a job highly valued as "elite-cultivated work". In this sense, the profession of teacher is an extremely meaningful job that can enhance growth of one's spirituality. Besides, teachers usually stay in a big office for a long time with the same educational purpose of balance development of Five Ways of Life (the moral, cognitive, physical, social and aesthetic) corresponding to what Milliman, Czaplewski, and Ferguson's (2003)[13] view: sense of community with focus on workplace spirituality emphasizes on sense of connection with co-workers, employees' supporting each other, and linking with a common purpose, proving that the three items can serve as dimensions in sense of community. Consequently, this research adopted the teachers as the subject and the workplace spirituality viewpoint to compile SOC Scale.

\section{Literature Review}

Based on workplace spirituality, this research explained the content. Workplace spirituality that focuses on the employees is an important trend in business in this century (Shellenbarger, 2000)[14]. Krishnakumar and Neck (2002)[15] mentioned that the reason why workplace spirituality attracts research is that people desire for experiencing spirituality increasingly not only in daily life but also at work. In addition, at work, spirituality can enhance commitment in the workplace (Krishnakumar \& Neck, 2002, Mougheli, Tayyebloo, \& Jamshidi, 2014)[15][16], and organizational efficacy will be raised (Jurkiewicz \& Giacalone, 2004)[17]. there is a positive significant relationship with toleration of employee expression(Jason \& Sudha, 2015) [18], quality of work life(Hojjati \& Hamidi, 2015)[19], job involvement(Van der Walt \& Swanepoel, 2015)[20], organizational citizenship behavior (Ghorbanifar \& Azma, 2014; Salimi \& Hamrahi, 2015)[21][22], and interpersonal relationship(Claude \& Zamor, 2003; Pielstick, 2005; Stevison, Dent, \& White, 2009)[23][24][25].

SOC is the important content of workplace spirituality, as Mirvis(1997)[26] mentions that work itself is being re-discovered as a source of spiritual growth and connection to others, Pfeffer (2003)[27] notes that an important dimension that people value at work is being able to feel part of a larger community or being interconnected. Duchon and Plowman (2005) [8] also say more than simply being present in a community, however, an individual must identify him/ herself as an integral part of the community in order for the community's benefits to be realized, so it is important to recognize that belonging can now be seen as part of what is required of a spirit-friendly work environment. All prove that SOC in perspective of workplace spirituality focuses on 
connection with others to obtain belonging and increase spirituality.

SOC based on workplace spirituality often appears in some scales of workplace spirituality, and SOC is just one of the dimensions. After Ashmos and Duchon (2000)[12] compiled Scale of Spirituality at Work, many scales refer to it for adaption. What listed below (Table 1) is Scales of Workplace Spirituality after 2000.

To view from dimensions of scales, Milliman et al(2003)[13] considers that workplace spirituality has three levels: 1. Individual level, or meaning of work. 2. Group Level: or SOC. 3. Organization Level: or alignment with organization values. Milliman et al. further point out that content of SOC includes sense of connection with co-workers, employees support each other, and linked with a common purpose. This research used SOC as the variable with the three levels, as described below:

\section{Sense of Connection}

The sense of connection is the foundation of personal relationships which develops through social interaction (Aguilar et al., 2015)[29]. Through social interaction, coworkers build up connection with each other, and due to emotional care, people obtain group's sense of belonging. As Beyer (1999) [30] says, people are social animals, so we look for group's sense of belonging by means of work. What called by this research "sense of connection" indicates freely express opinions among coworkers and connect with each other by sincere care in order to establish human relationship.

On this dimension, the items referable in Table 1 include: When I have a concern I represent it to the appropriate person; I feel part of a community in my immediate workplace (department, unit, etc.); People in my team/group feel as if they were part of a family; I experience a real sense of trust and personal connection with my coworkers; and I feel that the members of my team/group care about each other.

\section{Sense of Support}

Sense of support means the supportive and cooperative relationship between coworkers at work. In accordance with social support theory, when the employees are supported, their trust in the organization will be raised, and the relationship quality will be enhanced (Eisenberger, Huntington, Hutchison, \& Sowa, 1986)[31], so that communication of knowledge will be achieved (Farr \& Ford, 1990)[32]. In this regard, there are many items in Table 1 that can be consulted: Working cooperatively with others is valued; Believe people support each other, I am evaluated fairly here; When I have fears, I am encouraged to discuss them.

\section{Sense of Common Purpose}

Sense of common purpose indicates coworkers are consistent in regard of their viewpoints of the organizational goals, and it involves dimensions like what Bishop, Chertok, \& Jason (1997)[33] developed in the perception of sense of community scale, dimension of mission, where they consider that dimension of mission refers to the perception that one and his or her coworkers pursue common goals together. The referable items in Table 1 include: I share a strong sense of purpose and meaning with my coworkers; my team/group promotes the creation of a spirit of community; and I feel that the members of my team/group are linked by a common purpose.

Based on analysis above, this research classifies content of sense of community into sense of connection, sense of support, and sense of common purpose, and edits items according to the three dimensions--the more perception the teachers have on the dimension, the more they have sense of community. 
Table 1. Scale of Workplace Spirituality and Items of SOC

\begin{tabular}{|c|c|c|c|c|}
\hline Name & Year & $\begin{array}{c}\text { Title } \\
\text { Subject } \\
\text { Statistic Method } \\
\end{array}$ & Dimension and Name $(\alpha)$ & Item of SOC \\
\hline $\begin{array}{l}\text { Ashmos and } \\
\text { Duchon }\end{array}$ & $2000[12]$ & $\begin{array}{l}\text { Spirituality at } \\
\text { Work } \\
\text { Hospital } \\
\text { employees } \\
\text { Exploratory factor } \\
\text { analysis (EFA) }\end{array}$ & $\begin{array}{l}\text { 1. meaning at work }(\alpha=.86) \\
\text { 2. } \begin{array}{l}\text { conditions } \\
\text { community }(\alpha=.86)\end{array} \\
\text { 3. inner life }(\alpha=.80)\end{array}$ & $\begin{array}{l}\text { 1. My supervisor encourages my personal growth. } \\
\text { 2. I have had numerous experiences in my job } \\
\text { which have resulted in personal growth. } \\
\text { 3. When I have fears I am encouraged to discuss } \\
\text { them. } \\
\text { 4. When I have a concern I represent it to the } \\
\text { appropriate person. } \\
\text { 5. At work we work together to resolve conflict in a } \\
\text { positive way. } \\
\text { 6. I am encouraged to take risks at work. } \\
\text { 7. I am valued at work for who I am. }\end{array}$ \\
\hline $\begin{array}{l}\text { Milliman, et } \\
\text { al. }\end{array}$ & $2003[13]$ & $\begin{array}{l}\text { Workplace } \\
\text { Spirituality Scale } \\
\text { EMBA Students } \\
\text { Confirmatory } \\
\text { factor } \\
\text { analysis(CFA) }\end{array}$ & 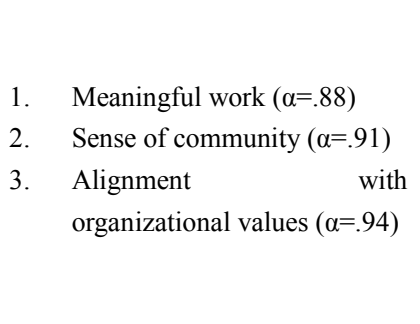 & $\begin{array}{l}\text { 1. Working cooperatively with others is valued } \\
\text { 2. Feel part of a community } \\
\text { 3. Believe people support each other. } \\
\text { 4. Feel free to express opinions. } \\
\text { 5. Think employees are linked with a common } \\
\text { purpose. } \\
\text { 6. Believe employees genuinely care about each } \\
\text { 7. Feel there is a sense of being a part of a family }\end{array}$ \\
\hline $\begin{array}{l}\text { Duchon and } \\
\text { Plowman }\end{array}$ & $2005[28]$ & $\begin{array}{l}\text { The Meaning and } \\
\text { Purpose at Work } \\
\text { Hospital } \\
\text { employees } \\
\text { Cronbach's } \\
\text { Coefficient Alpha }\end{array}$ & $\begin{array}{l}\text { 1. Meaning at work }(\alpha=.86) \\
\text { 2. Community }(\alpha=.86) \\
\text { 3. Inner life }(\alpha=.82) \\
\text { 4. Work unit community }(\alpha=.87) \\
\text { 5. Work unit and meaningful } \\
\text { work }(\alpha=.91)\end{array}$ & $\begin{array}{l}\text { 1. I feel part of a community in my immediate } \\
\text { workplace (department, unit, etc.). } \\
\text { 2. My supervisor encourages my personal growth. } \\
\text { 3. I have had numerous experiences in my job } \\
\text { which have resulted in personal growth. } \\
\text { 4. When I have fears I am encouraged to discuss } \\
\text { them. } \\
\text { 5. At work we work together to resolve conflict in a } \\
\text { positive way. } \\
\text { 6. I am evaluated fairly here. } \\
\text { 7. I am encouraged to take risks at work. } \\
\text { 8. I am valued at work for who I am. }\end{array}$ \\
\hline $\begin{array}{l}\text { Kinjerski and } \\
\text { Skrypnek }\end{array}$ & $2006[34]$ & $\begin{array}{c}\text { Spirit at Work } \\
\text { Scale employees of } \\
\text { university } \\
\text { EFA }\end{array}$ & $\begin{array}{ll}\text { 1. } & \text { Engaging work }(\alpha=.91) \\
\text { 2. } & \text { Sense of Community }(\alpha=.87) \\
\text { 3. } & \text { mystic experience }(\alpha=.86) \\
\text { 4. } & \text { spiritual connection }(\alpha=.88) \\
\text { 5. } & (\text { Total Scale } \alpha=)=.93)\end{array}$ & $\begin{array}{l}\text { 1. I feel like I am part of "a community" at work. } \\
\text { 2. I experience a real sense of trust and personal } \\
\text { connection with my coworkers. } \\
\text { 3. I share a strong sense of purpose and meaning } \\
\text { with my coworkers about our work }\end{array}$ \\
\hline $\begin{array}{l}\text { Rego and e } \\
\text { Cunha }\end{array}$ & $2008[35]$ & $\begin{array}{l}\text { Spirituality at } \\
\text { Work } \\
\text { Hospital } \\
\text { employees } \\
\text { EFA }\end{array}$ & $\begin{array}{l}\text { 1. Team's sense of community } \\
\text { 2. Alignment between } \\
\text { organizational and individual } \\
\text { value } \\
\text { 3. Sense of contribution to the } \\
\text { community } \\
\text { 4. Sense of enjoyment at work }\end{array}$ & $\begin{array}{l}\text { 1. People in my team/group feel as if they were } \\
\text { part of a family. } \\
\text { 2. My team/group promotes the creation of a spirit } \\
\text { of community. } \\
\text { 3. I feel that the members of my team/group } \\
\text { support each other. } \\
\text { 4. I feel that the members of my team/group care } \\
\text { about each other. } \\
\text { 5. I feel that the members of my team/group are } \\
\text { linked by a common purpose. }\end{array}$ \\
\hline $\begin{array}{l}\text { Abdullah and } \\
\text { Ismail }\end{array}$ & $2013[36]$ & $\begin{array}{l}\text { Scale of Malay } \\
\text { Version } \\
\text { Workplace } \\
\text { Spirituality } \\
\text { Teachers } \\
\text { EFA } \\
\text { CFA }\end{array}$ & $\begin{array}{l}\text { 1. Work Meaningful } \\
\text { 2. Community Sense } \\
\text { 3. Coherent of Organizational } \\
\text { Value } \\
\text { (The alphas are ranging from } .83 \text { to } \\
\quad \text { a high of } .93 \text { ) }\end{array}$ & $\begin{array}{l}\text { 1. Working is crucially important. } \\
\text { 2. Appreciate the cooperation with others } \\
\text { 3. Partially related with school community. } \\
\text { 4. Workplace peers should support each other. } \\
\text { 5. Working colleagues are connected between each } \\
\text { other due to the existence of shared } \\
\text { responsibility. } \\
\text { 6. Should be emphatic with each other. }\end{array}$ \\
\hline
\end{tabular}




\section{Research Design}

\section{Review of Item Pool by Experts}

In process of developing Sense of Community Scale, after drafting the initial items, we invited Dr. Shiao, Dr. Luo, and Dr. Chen (all professors in university with published articles or books on spirituality) to provide theoretical opinions and Mr. Liu (senior high school teacher with consultancy major and strength at life education) to provide practical viewpoints for our further modification.

\section{Demographic Profile of Respondents}

Two investigations were conducted for SOC Scale, participants rated how agree each item was for them along a 5 -point scale ranging from " $1=$ unagree, " $2=$ a little bit agree", " $3=$ partially agree" , " $4=$ mostly agree" to " $5=$ completely agree": 1 . The $1^{\text {st }}$ round: pre-test questionnaire were used to verify the initial model with 235 samples; 2 . The 2 nd round: one item was deleted in the first
CFA, so the initial model was modified in order to investigate another batch of samples for review $(N=378)$. Regarding SEM sample quantity, Schumacker and Lomax (1996)[37] think that SEM studies' sample quantity is between 200 to 500 mostly, and our two batches of samples are alignment with this claim.

Background configuration is listed in Table 2.

\section{Data Process}

The first-order CFA model was employed to examine the three proposed dimensions of SOC: Sense of connection, Sense of support, Sense of common purpose. The analysis included assessing fit of the initial model, modified model, and cross-validity model. The initial measurement model consisted of three latent variables with their indicators: Sense of connection (four indicators), Sense of support (five indicators), Sense of common purpose (five indicators).

Table 2. Background configuration

\begin{tabular}{|c|c|c|c|c|c|}
\hline & & \multicolumn{2}{|c|}{$\begin{array}{c}\text { 1st Investigation } \\
(N=235)\end{array}$} & \multicolumn{2}{|c|}{$\begin{array}{c}\text { 2nd Investigation } \\
\quad(N=378)\end{array}$} \\
\hline & & Times & $\%$ & Times & $\%$ \\
\hline \multirow[t]{2}{*}{ Gender } & 1. Male & 60 & 25.5 & 122 & 32.3 \\
\hline & 2.Female & 174 & 74.0 & 255 & 67.5 \\
\hline \multirow[t]{2}{*}{ Also Administrative Personnel } & 1.No & 93 & 39.6 & 166 & 43.9 \\
\hline & 2. Yes & 140 & 59.6 & 212 & 56.1 \\
\hline \multirow[t]{2}{*}{ Marital Status } & 1. Married & 179 & 76.2 & 76.2 & 76.8 \\
\hline & 2. Unmarried & 52 & 22.1 & 23.0 & 23.2 \\
\hline Length of service & & $M=16.82$ & $S D=7.64$ & $M=13.54$ & $S D=8.23$ \\
\hline
\end{tabular}

Table 3. Review Results of Sense of Community Experts

\begin{tabular}{|c|c|c|c|c|}
\hline Dimension & & Item after Experts Review & $\begin{array}{l}\text { Initial Model } \\
\text { Code }\end{array}$ & Modified Model Code \\
\hline \multirow{4}{*}{ Sense of connection } & 1. & I feel that I am part of the school. & $\mathrm{C} 1$ & $\mathrm{C} 1$ \\
\hline & 2. & We express opinions freely among coworkers. & $\mathrm{C} 2$ & $\mathrm{C} 2$ \\
\hline & 3. & Affection for school coworkers is family-like. & $\mathrm{C} 3$ & $\mathrm{C} 3$ \\
\hline & 4. & I am pleased to be generous to others in school. & $\mathrm{C} 4$ & $\mathrm{C} 4$ \\
\hline \multirow[t]{5}{*}{ Sense of support } & 5. & I value cooperation between coworkers very much. & C5 & $\mathrm{C} 5$ \\
\hline & 6. & Coworkers and I support each other in school. & C6 & C6 \\
\hline & 7. & I am pleased to help coworkers actively. & $\mathrm{C} 7$ & $\mathrm{C} 7$ \\
\hline & 8. & $\begin{array}{l}\text { When I am stuck in difficulty, coworkers will help me face it } \\
\text { and deal with it. }\end{array}$ & $\mathrm{C} 8$ & $\mathrm{C} 8$ \\
\hline & 9. & Coworkers make efforts together to solve the conflict. & C9 & C9 \\
\hline \multirow[t]{5}{*}{$\begin{array}{l}\text { Sense of common } \\
\text { purpos. }\end{array}$} & 10. & Coworkers all take meeting students' need as the first priority. & $\mathrm{C} 10$ & $\mathrm{C} 10$ \\
\hline & 11. & Coworkers always bear raising the school's prestige in mind. & $\mathrm{C} 11$ & $\mathrm{C} 11$ \\
\hline & 12. & Coworkers endeavor to enhance harmony in school. & $\mathrm{C} 12$ & $\mathrm{C} 12$ \\
\hline & 13. & $\begin{array}{l}\text { Coworkers extremely value school administrative unit's } \\
\text { working efficiency.. }\end{array}$ & $\mathrm{C} 13$ & $\mathrm{C} 13$ \\
\hline & 14. & Coworkers all support what is promoted by school. & $\mathrm{C} 14$ & $\begin{array}{c}\text { (Deleted in the initial model } \\
\text { stage) }\end{array}$ \\
\hline
\end{tabular}




\section{Results and Discussion}

\section{Review of Item Pool by Experts}

Four experts were invited to review the initial item draft, and we delete the item based on their opinions. There were 14 items initially, after reviewed, 8 remained the same, and 6 were further modified: "the coworkers in the school are like our family" was modified as "affection for school coworkers is family-like".

\section{CFA}

\section{(1) Correlation Coefficient of Latent Variable}

We added up score of each dimension of SOC and employed correlation coefficient; the results show that correlation of the three latent variables ranges between .68-.73, all achieving significantly positive correlation $(p<.001)$ (see Table 4$)$.

Table 4. Latent variables' correlation coefficient and descriptive data

\begin{tabular}{lccccc}
\hline Latent Variables and No. & 1 & 2 & 3 & $M$ & $S D$ \\
\hline 1.Sense of connection & 1 & & & 15.30 & 2.57 \\
2. Sense of support & $.73 * * *$ & 1 & & 19.59 & 3.08 \\
3.Sense of common purpose & $.72 * * *$ & $.68 * * *$ & 1 & 17.56 & 3.17 \\
\hline
\end{tabular}

$N=378$.

$* * * p<.001$.

\section{(2) Initial Model}

The 14 items of the three factors after reviewed by the experts are called the initial model. After investigating 378 teachers, CFA was used for verification. With correlation coefficient analysis, it is confirmed that there is significantly positive correlation between three latent variables and the total score. Then, CFA was conducted, and the results are as shown in Fig. 1: In the initial model, regarding the overall fit, $\chi^{2}=239.13, d f=74, p=.00, \mathrm{RMSEA}=.08, \mathrm{GFI}=.90$, $\mathrm{AGFI}=.86$, IFI $=.92, \mathrm{TLI}=.93$, and $\mathrm{CFI}=.94$, among which $\chi^{2}$ reaches the significant standard, not meeting the standard, RMSEA meets the standard of less than .10, GFI, IFI, TLI, and CFI all meeting the standard of more than .90, but $\mathrm{AGFI}=.86$, not meeting the standard of more than .90 . Overall, the results show that the initial model is fit as a whole.

From the 14 indicators' factor loading, C14's (Coworkers all support what is promoted by school.) factor loading is . 36 . Bogozzi and Yi (1988)[38] proposed that the factor loading between the indicators should fall between .50-.95, and Tabachnica and Fidell (2007)[39] consider that $\lambda \geqq .55$ can be regarded as good. Our research balances the fit of the overall model, so we took Tabachnica and Fidell's $\lambda \geqq .55$, and deleted $\mathrm{C} 14$.

\section{(3) Modified Model}

Regarding the overall fit, after deleting $\mathrm{C} 14$, the initial model became 13 items of the three factors called modified model, and the inspection results are (see Fig. 1): $\chi^{2}=222.75$, $d f=62, p=.00, \mathrm{GFI}=.92, \mathrm{RMSEA}=.09, \mathrm{GFI}=.90, \mathrm{AGFI}$ $=.85, \mathrm{NFI}=.93, \mathrm{IFI}=.95, \mathrm{TLI}=.94$, and $\mathrm{CFI}=.95$. Among the fit indicators, $\chi^{2}$ and AGFI do not meet the standard, and the others like RMSEA, GFI, NFI, IFI, TLI, and CFI all meet the standard. As Anderson and Gerbing (1984)[40] claim that $A G F I \geq 0.80$ is fair, the overall modified model is fit.

In respect with the modified model's preliminary fit, the inspection results show that: 1 . In $\Theta_{\varepsilon}$ matrix entries, error variance of $\varepsilon_{1}$ to $\varepsilon_{13}$ are both positive. 2. The $t$ value of all error variances falls between 11.31-17.39, and all reaches the significant standard of .001. 3. The standard error of the parameters is between $.03-.04$, not very big standard error. 4 . The factor loading $\left(\lambda_{1}-\lambda_{13}\right)$ of the latent variable and its indicator ranges between $.65-.86$, meeting the standard of $>.50$ and $<.95$. Based on above, all inspection results meet the standard, showing good item quality and no offending estimates (the output data do not exceed the acceptable range) (Hair, Anderson, Tatham, \& Black, 1998)[41].

\section{(4) Analysis of Fit of Internal of Model}

On individual reliability, the individual reliability refers to indicator's (item) square of factor loading. The indicator has 13items $\left(\lambda_{1}-\lambda_{13}\right)$, and the individual reliability ranges between .42-.70. Bogozzi and Yi (1988 )[38] consider the individual reliability must reach more than .50 , or the indicator's factor loading must exceed .71. Our indicator include $\mathrm{C} 3$ does not meet this standard, but the remaining 12 items all meet the standard.

For composite reliability of the latent variables: the composite reliability of the three latent variables are Sense of connection .84, Sense of support.90, and Sense of common purpose .88, which all meet the standard of $>.60$, meaning that the indicator of the three latent variable can predict $84 \%$ or above. Namely, the three latent variables have basic stability in respect with reflecting the real scores.

As for the average variance extracted, the average variance extraction of the three latent variables are Sense of connection .57, Sense of support .65, and Sense of common purpose .65 , all meeting the standard of $>.50$, and meaning the indicators can reflect the constructed latent variables.

In regard of construct discrimination, this research adopted the competing models (Anderson \& Gerbing, 1988)[40] to inspect the construct discrimination of the latent variables: the chi square of between the three restrictive models and nonrestrictive models are 139.69, 144.72, and 83.90, all larger than the threshold standard $3.84(p<.05)$ (see Table 5), which means that the chi square differecne $\left(\Delta \chi^{2}\right)$ between the three restrictive models and the nonrestrictive model reach the significant standard, .05 . Meanwhile, the hypothesis that correlation between any two paired latent variable is complete correlation $(\rho=1)$ fails, because the latent traits signified by the three latent variables are significant different.

Based on above, the fit of internal of model is acceptable, that is, internal quality of the modified model with 11 items of the three factors is acceptable. 


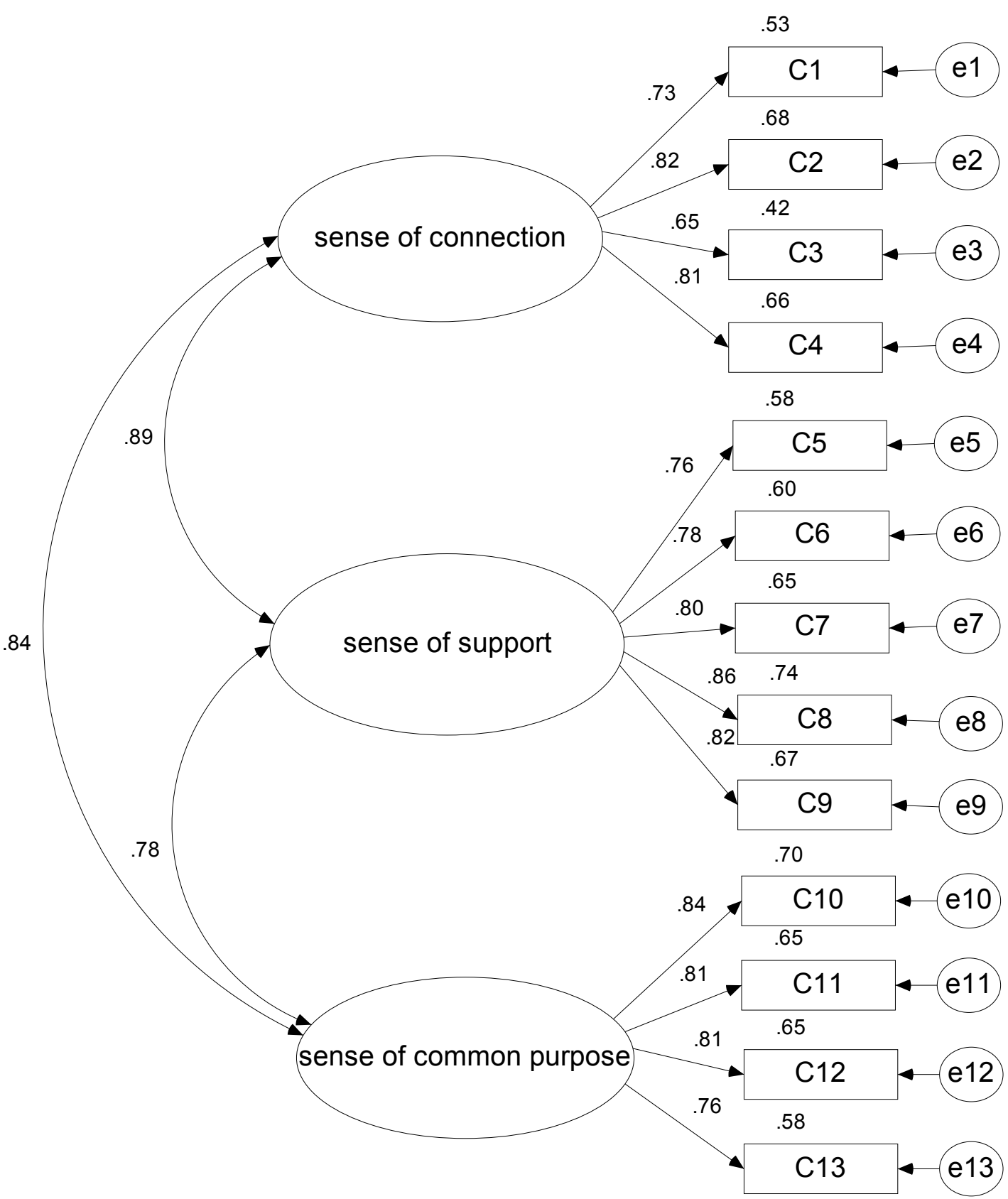

Note: Data on the indicator is individual reliability.

Figure 1. Fit evaluation of the modified model

Table 5. Sense of community Scale's Construct Discrimination Analysis Summary

\begin{tabular}{|c|c|c|c|c|c|c|c|}
\hline \multirow{2}{*}{ Paired latent variable } & \multicolumn{3}{|c|}{$\begin{array}{l}\text { Restrictive model } \\
\text { (B) }\end{array}$} & \multicolumn{3}{|c|}{$\begin{array}{l}\text { Nonrestrictive model } \\
\text { (A) }\end{array}$} & \multirow{2}{*}{$\begin{array}{c}\chi^{2} \begin{array}{c}\text { difference } \\
(\mathrm{B}-\mathrm{A})\end{array} \\
\Delta \chi^{2}\end{array}$} \\
\hline & $\rho 1$ & $d f$ & $\chi^{2}$ & $\rho$ & $d f$ & $\chi^{2}$ & \\
\hline Sense of connection — sense of support & 1 & 27 & 288.03 & .89 & 26 & 148.34 & $139.69^{*}$ \\
\hline sense of support- Sense of common purpose & 1 & 27 & 297.82 & .77 & 26 & 153.10 & $144.72 *$ \\
\hline Sense of connection - Sense of common purpose & 1 & 27 & 118.78 & .84 & 19 & 34.88 & $83.90 *$ \\
\hline
\end{tabular}

Note: * refers to the chi square values of the restrictive model and nonrestrictive model are larger than 3.84 , reaching the significant standard of .05. 


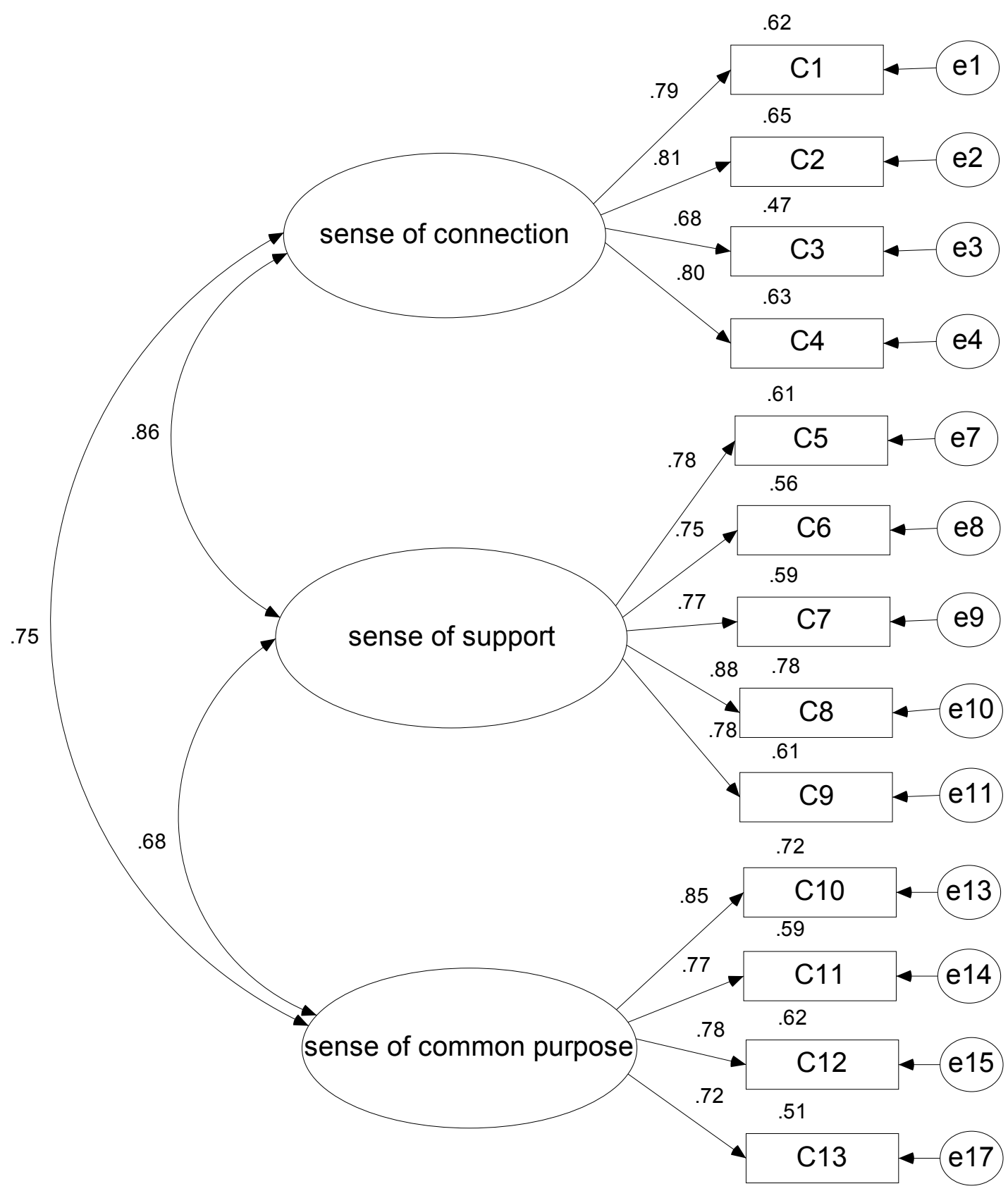

Figure 2. Cross-validity model's fit evaluation (the standard solution )

\section{Cross- validity of the Model}

Since the model was modified, so we investigated another batch of samples $(N=204)$ to confirm whether the model with 13 items of the three factors are stable or not. The results (See Fig. 2) are: $\chi^{2}=156.14, d f=62, p=.00$, RMSEA $=.09, \mathrm{GFI}=.88, \mathrm{AGFI}=.83, \mathrm{NFI}=.91, \mathrm{IFI}=.94, \mathrm{TLI}=.93$, and $\mathrm{CFI}=.95$. Among the fit indicators, $\chi^{2}$ and AGFI do not meet the standard. As Anderson and Gerbing (1984)[40] indicate it is fair when GFI $\geq .85$, AGFI $\geq 0.80$, so the RMSEA, GFI, AGFI, IFI, TLI, and CFI all meet the standard. As a whole, the modified model is overall fit, and the Sense of community Scale with 13 items of the three factors model is established.

\section{Discussion}

The purpose of this research is to develop Taiwan Teacher's Sense of community Scale for relevant research. In process of developing the scale:

To start with, according to our literature analysis, the theoretical foundations on sense of community include sociology, like the Sense of Community Scale developed by Doolittle and MacDonald (1978)[8], the dimensions are Supportive Climate, Family Life Cycle, Safety, Informal Interaction, Neighborly Integration, and Localism; sociological psychology like Perceived Sense of Community Scale by Bishop, Chertok, and Jason (1997)[33] with dimensions of Mission(perception that the members can transcend the goal), Connection (perception of the accepted 
members), and Reciprocal responsibility (perception that the members can respond to each other's need). In this research, through workplace spirituality, Sense of connection, Sense of support, and Sense of common purpose are concentrated. The above theories have something in common, such as focusing on interpersonal interaction, particularly identification with membership. In McMillan et al's (1996)[13] view, Membership refers to one's sense of belonging and to a sense of confidence that one has as a member as well as the aspect of acceptance from the group that facilitates belonging. However, workplace spirituality's SOC values membership between coworkers at workplace, so the interaction range is not as big as that of sociology and sociological psychology.

It is found that unlike SOC based on sociology and sociological psychology is an individual research variable, SOC in relative workplace spirituality scales is just one of the dimensions. Besides, according to Milliman et al's (2003 )[13] viewpoint, workplace spirituality related SOC can be further divided into sense of connection with co-workers, employees support each other, and are linked with a common purpose. As a result, we referred to relative workplace spirituality scales, and combine teacher's work content to compile three dimensions of sense of connection, support, and common purpose with 14 items.

The item pool was reviewed by experts, and then proceed CFA, which was further tested with three models: 1 . the initial model test: after review of item pool by experts, the three factors' 14 items is called the initial model, which is overall fit after testing. But, since item C14's factor loading (.36) does not meet what was proposed by Bogozzi and Yi (1988)[38] .50-.95 nor the standard of $\lambda \geqq .55$ set up by Tabachnica and Fidell (2007)[39], "C14" was deleted. The content is "Coworkers all support what is promoted by school", showing teachers hold different viewpoints about it, and the relevance is also low. 2. Modified model: After deleting C14, we further tested it and the results overall fit. Regarding the modified model's preliminary fit, we found that there was no offending estimation, the internal fit is acceptable (including individual reliability, composite reliability, average variance extraction, and construct discrimination). 3. Cross-validity model: The test results show overall fit of this model. Up to now, Models of Teacher's Sense of Community Scale with 13 items of the three factors are ascertained: Dimension of Sense of connection covers four items: " I feel that I am part of the school", " We express opinions freely among coworkers", "Affection for school coworkers is family-like", and " I am pleased to be generous to others in school". Sense of connection in this research means coworkers can freely express their opinions at workplace and connect with each other by sincerity and care, so that human relationship is established. Secondly, Sense of support is composed by "I value cooperation between coworkers very much", "I am pleased to help coworkers actively", "When I am stuck in difficulty, coworkers will help me face it and deal with it", and "Coworkers make efforts together to solve the conflict". In this research, Sense of support refers to coworkers have supportive and cooperative relationship at work, and the 5 items above are consistent to such spirit. Finally, Sense of common purpose consists of " Coworkers all take meeting students' need as the first priority", " Coworkers always bear raising the school's prestige in mind", " Coworkers endeavor to enhance harmony in school", and " Coworkers extremely value school administrative unit's working efficiency", all meet the implication of Sense of common purpose in this research, meaning that coworkers have the same opinion towards the organizational goals.

There are totally 13 items in the scale developed by this research. To see from some SOC scales, like Brief Sense of Community Scale proposed by Peterson, Speer, and McMillan (2008)[1], they tested first-order and second-order models using CFA. Besides, an 8-item Brief Sense of Community Scale (BSCS) was developed to represent the SOC dimensions of Needs fulfillment, Group membership, Influence, and Shared emotional connection, and each dimension has two items. Moreover, Oh, Ozkaya, and LaRose's (2014)[42] Sense of community has only 3 items--"I feel sense of contact with people who care for me", "I feel connected with others who are important to me", and "I feel intimate with people I spent time with". In this research, we have three factors, and each with 4-5 items, so it meet the standard set up by Bollen (1989)[43] that each factor must have at least three items.

To sum up, Teacher's Sense of Community Scale developed by this research started from literature analysis, through drafting 14 items for the experts to review, CFA test for acceptable reliability and validity, to the outcome as research tool for those who make a survey on Taiwan teacher's sense of community.

\section{REFERENCES}

[1] N. A. Peterson, P. W. Speer, D. W. McMillan, Validation of a Brief Sense of Community Scale: Confirmation of the principal theory of sense of community. Journal of community psychology, Vol. 36, No. 1, 61-73, 2008.

[2] M. M. Cohn, R. B. Kottkamp, Teachers, the missing voice in education. Albany, NY: SUNY Press, 1993.

[3] D. W. McMillan, Sense of community. Journal of community psychology, Vol. 24, No. 4, 315-325, 1996.

[4] D. Wilkinson, The multidimensional nature of social cohesion: Psychological sense of community, attraction, and neighboring. American Journal of Community Psychology, Vol. 40, 214-229, 2007.

[5] D. A. Long, D. Perkins, Community social and place predictors of sense of community: A multilevel and longitudinal analysis. Journal of Community Psychology, Vol. 35, No. 5, 563-581, 2007.

[6] B. Zani, E. Cicognani, C. Albanesi, Adolescents' sense of community and feeling of unsafety in the urban environment. Journal of Community and Applied Social Psychology, Vol. 11, 475-489, 2001. 
[7] M. A. Bodla, T. Afza, H. Ali, B. Naeem, Role of psychological sense of community in enhancing employee's well-being. European Online Journal of Natural and Social Sciences, Vol. 4, No. 2, 256-259, 2015.

[8] R. J. Doolittle, D. MacDonald, Communication and a sense of community in a metropolitan neighborhood: A factor analytic examination. Communication Quarterly, Vol. 26, No. 3, 2-7, 1978. Retrieved from

http://web.a.ebscohost.com/ehost/pdfviewer/pdfviewer?sid= ae7073c4-96d7-46ce-aa87-a9011c30f2be\%40sessionmgr400 $4 \&$ crlhashurl $=$ login.aspx $\% 253$ fdirect $\% 253$ dtrue $\% 2526$ profil e\%253dehost $\% 2526$ scope $\% 253$ dsite $\% 2526$ authtype $\% 253 \mathrm{dc}$ rawler\%2526jrnl\%253d01463373\%2526AN\%253d1858673 $0 \&$ hid $=4212 \&$ vid $=0$

[9] D. W. McMillan, D. M. Chavis, Sense of community: A definition and theory. Journal of community psychology, Vol. 14, No. 1, 6-23, 1986.

[10] I. I. Mitroff, E. A. Denton, A study of spirituality in the workplace. MIT Sloan Management Review, Vol. 40, No. 4, 83, 1999.

[11] W. C. Miller, How do we put our spiritual values to work? In J. Renesch (Ed.), New traditions in business: Spirit and leadership in the 21 st century (pp. 69-80). San Francisco, CA: Berrett-Koehler, 1992.

[12] D. Ashmos, D. P. Duchon, Spirituality at work: A conceptualization and measure. Journal of Management Inquiry, Vol. 9, No. 2, 134-145, 2000. Retrieved from http://ejournal.narotama.ac.id/files/ProQuest_54883215.pdf

[13] J. Milliman, A. Czaplewski, J. J. Ferguson, Workplace spirituality and employee work attitudes: A exploratory empirical assessment. Journal of Organizational Change Management, Vol. 16, No. 4, 426-447, 2003.

[14] S. Shellenbarger, More relaxed boomers, fewer workplace frills and other job trends. Wall Street Journal, p. B-I, December 27, 2000.

[15] S. Krishnakumar, C. P. Neck, The "what", "why" and "how" of spirituality in the workplace. Journal of managerial psychology, Vol. 17, No. 3, 153-164, 2002.

[16] A. Mougheli, B. J. Tayyebloo, A .Jamshidi, A survey on the relation of workplace spirituality and service quality with organizational commitment case study: Tax Affairs Office of Kohkilooye and Boveirahmad, Iran. International Journal of Research in Organizational Behaviour and Human Resource Management, Vol. 2, No. 1, 361-370, 2014.

[17] C. L .Jurkiewicz, R. A. Giacalone, A values framework for measuring the impact of workplace spirituality on organizational performance. Journal of Business Ethics, Vol. 49, No. 2, 129-142, 2004.

[18] A. P. Jason, S. Sudha, Workplace Spirituality and Toleration of Employee Expression-An Exploratory Study. Purushartha: A Journal of Management Ethics and Spirituality, Vol. 7, No. 1, 88-97, 2015.

[19] H. Hojjati, N. Hamidi, An investigation into the relationship between workplace spirituality and the quality of working life case study: Razan Department of Education. Kuwait Chapter of the Arabian Journal of Business and Management Review, Vol. 4, No. 11, 17-26, 2015.
[20] F. Van der Walt, H. Swanepoel, The relationship between workplace spirituality and job involvement: A South African study. African Journal of Business and Economic Research, Vol. 10, No. 1, 95-116, 2015.

[21] M. Ghorbanifar, F. Azma, Workplace spirituality and organizational citizenship behavior: Evidence from banking industry. Management Science Letters, Vol. 4, No. 8, 1685-1692, 2014.

[22] G. Salimi, F. Hamrahi, The use of structural equation modeling and the effect of spirituality in workplace on organizational citizenship behavior at Shiraz University of Medical Sciences. Journal of Health Administration, Vol. 18, No. 60, 37-48, 2015.

[23] J. Claude, G. Zamor, Workplace spirituality and organizational performance. Public Administration Review, Vol. 63, No. 3, 355-363, 2003. Retrieved from http://onlinelibrary.wiley.com/doi/10.1111/1540-6210.00295 $/ \mathrm{pdf}$

[24] C. D. Pielstick, Teaching spiritual synchronicity in a business leadership class. Journal of Management Education, Vol. 29, No. 1, 158-159, 2005.

[25] M. Stevison, E. Dent, D. White, Toward a greater understanding of spirit at work: A model of spirit at work and outcomes. Paper presented at Academy of Management Proceedings of Academy of Management Annual Meeting, Chicago, IL, August, 2009.

[26] P. H. Mirvis, Soul work in organizations. Organization Science, Vol. 8, No. 2, 193-206, 1997.

[27] J. Pfeffer, Business and the spirit. In R. A. Giacalone \& C. L. Jurkiewicz(Eds.) Handbook of workplace spirituality and organizational performance(pp. 29-45). Armonk, NY: Me Sharpe, 2003.

[28] D. T. Duchon, A. Plowman, Nurturing the spirit at work: Impact on work unit performance. The Leadership Quarterly, Vol. 16, 807-833, 2005.

[29] L. Aguilar, G. Downey, R. Krauss, J. Pardo, S. Lane, N. Bolger, A dyadic perspective on speech accommodation and social connection: both partners' rejection sensitivity matters. Journal of personality, 2015. Retrieved from http://onlinelibrary.wiley.com/doi/10.1111/jopy.12149/pdf

[30] J. M. Beyer, Culture, meaning and belonging at work. Paper presented at the 1999 Chicago Academy of Management Meeting, Chicago, IL, August, 1999.

[31] R. Eisenberger, R. Huntington, S. Hutchison, D. Sowa, Perceived organizational support. Journal of Applied Psychology, Vol. 71, 500-507, 1986.

[32] J. L. Farr, C. M. Ford, Individual innovation. In M. A. West \& Farr, J. L. (Eds.), Innovation and creativity at work: Psychological and organizational strategies (pp. 63-80). Oxford, England: John Wiley \& Sons, 1990.

[33] P. D. Bishop, F. Chertok, L. A. Jason,. Measuring sense of community: Beyond local boundaries. Journal of Primary Prevention, Vol. 18, No. 2, 193-212, 1997.

[34] V. Kinjerski, B. J. Skrypnek,. Creating organizational conditions that foster employee spirit at work. Leadership \& Organization Development Journal, Vol. 27, No. 4, 280-295, 
2006.

[35] A. Rego, M. P. e Cunha, Workplace spirituality and organizational commitment: An empirical study. Journal of organizational change management, Vol. 21, No. 1, 53-75, 2008. Retrieved from

http:/homepages.se.edu/cvonbergen/files/2013/01/Workplac e-Spirituality-and-Organizational-Commitment_An-Empiric al-Study.pdf

[36] A. G. K. Abdullah, A. Ismail, Validating and standardization the Scale of Malay Version Workplace Spirituality from Malaysian school settings. International Journal of Asian Social Science, Vol. 3, No. 6, 1418-1430, 2013. Retrieved from http://www.pakinsight.com/pdf-files/ijass\%203 (6), 201418-1430.pdf

[37] R. E. Schumacker, R. G. Lomax, A beginner's guide to structural equation modeling. Mahwah, NJ: Lawrence Erlbaum Associates, 1996.

[38] R. P. Bagozzi, Y. Yi, On the evaluation of structural equation models. Academic of Marketing Science, Vol. 16, 74-94, 1988.

[39] B. G. Tabachnica, L. S. Fidell, Using multivariate statistics(4 ed.). Needham Heights, MA: Allyn and Bacon, 2001.

[40] J. C. Anderson, D. W. Gerbing, The effect of sampling error on convergence, improper solutions and goodness-of-fit indices for maximum likelihood confirmatory factor analysis. Psychometrika, Vol. 49, 155-173, 1984.

[41] J. F. Hair, R. E. Anderson, R. L. Tatham, W. C. Black, Multivariate data analysis (5th ed.). Englewood Cliffs, NJ: Prentice-Hall, 1998

[42] H. J. Oh, E. Ozkaya, R. La Rose, How does online social networking enhance life satisfaction? The relationships among online supportive interaction, affect, perceived social support, sense of community, and life satisfaction. Computers in Human Behavior, Vol. 30, 69-78, 2014.

[43] K. A. Bollen, Structural equations with latent variables. New York, NY: Wiley \& Sons, 1989. 